\title{
The Rise of the Academies: Continuity or Change?
}

\author{
Kim Tolley
}

In his book, The Age of the Academies, Theodore R. Sizer argued that academies represented a significant break from the relatively narrow schooling that had been previously available to students in the early Latin grammar schools. ${ }^{1}$ In his view, the proliferation of academies heralded a new age in education, one more reflective of the Enlightenment values promoted by such Republican leaders as Benjamin Franklin, Thomas Jefferson, or Benjamin Rush. After thirty-five years of additional scholarship on academies, does Sizer's thesis still stand? This essay investigates the range of educational institutions that provided some form of advanced schooling to Americans just preceding and concurrent with the founding of the earliest academies. It examines the differences and similarities among a number of northern and southern early nineteenth-century schools in order to address the following question: to what extent did schools calling themselves academies represent a distinctly new turn in the history of American education? By clarifying the relations between the various types of institutions during the postcolonial period, I conclude that the historical significance of the early academy movement is broader than the intellectual or curricular reform discussed by Sizer.

There has been a great deal of confusion in published secondary sources about the nature of the diverse educational institutions during the late eighteenth century. For instance, some authors refer to a dame school as an institution providing only rudimentary instruction in reading and writing to very young children, while other authors refer to any institution run by a woman as a dame school, even one providing relatively advanced instruction to older students. To understand the origins of the academies, it is important to comprehend the educational institutions that preceded them. Because the terms venture scbool, dame school, academy, and seminary

Kim Tolley is an independent scholar. She is currently revising a book manuscript entitled "Standing at the Portals: The Science Education of American Girls, 1795-1932" and collaborating with Margaret Nash on a series of papers devoted to the life of antebellum teacher Susan Nye Hutchison. Her research interests include nineteenth-century schooling and American culture, the sociology of teaching in the antebellum era, and science and popular culture.

'Theodore R. Sizer, The Age of the Academies (New York: Teachers College, Columbia University, 1964). 
are often used interchangeably in the existing secondary literature, the following discussion begins with a number of working definitions.

\section{Working Definitions}

A venture school is defined here as an institution supported entirely by tuition. Eighteenth- and nineteenth-century venture schools were entrepreneurial in nature, characterized by market supply and demand. Both male and female venture school instructors marketed their services to prospective students through newspaper advertisements. A sample of eighty-one venture schools analyzed for this study placed newspaper advertisements during the period from 1808 to 1842 . Although many venture schools offered instruction in just one or two subjects, such as dancing, languages, navigation and surveying, or needlework, the schools discussed in this paper claimed to offer a diverse curriculum that went beyond the basic studies of reading, writing, and spelling. ${ }^{2}$ A dame school is defined here as a specific type of venture school, often run by a woman in her own home. Dame schools enabled students to gain a basic literacy necessary to read Bible passages, knowledge of simple sums, and skill in sewing. ${ }^{3}$ In some cases the daughters of freemen had similar opportunities to obtain a rudimentary education in dame or town schools, although in the South the education of slaves remained subject to the disposition of the master.

Town schools and church schools appeared in northern and southern local communities during the eighteenth century. Such institutions provided a basic education in literacy and numeracy and received varying degrees of financial support from the groups that sponsored them. Following the colonial General Court's injunction for grammar schools to prepare youth for the university, a few of the larger towns established Latin grammar schools for boys already able to read. In such schools as Boston Latin Grammar School, boys spent six or seven years reading arithmetic and Latin texts. Middle- and upper-class parents desirous of providing a relatively advanced

${ }^{2}$ The venture schools and academies comprising the sample for this study placed advertisements in the following newspapers: The Columbian Centinel (Massachusetts: 1827, Jan., 1831-Mar. 1833); The American Mercury (Connecticut: Jan., 1820 - 28); The Philadelpbia Gazette \& Universal Daily Advertiser (Pennsylvania: 1824); The New York Evening Post (New York: Aug. 1, 1835-May 31, 1836); The Richmond Enquirer (Virginia: Sept. 29, 1835-Nov. 17, 1837); The Maryland Gazette (Maryland: Jan. 5, 1832-Oct. 22, 1835); The Baltimore Sun (Maryland: Aug. 12, 1842-Aug. 23, 1842); The Globe (Washington, D.C.: 1831); The Daily National Intelligencer (Washington D.C.: 1825). Another important source are the newspaper advertisements included in North Carolina Schools and Academies 1790-1840: A Documentary History ed. Charles L. Coon (Raleigh, NC: Edwards \& Broughton, 1915).

${ }^{3}$ Dame schoolteachers operated schools from their homes during the seventeenth century and flourished among such groups as the Quakers. See Joan Jensen, "Not Only Ours But Others: The Quaker Teaching Daughters of the Mid-Atlantic, 1790-1850, "History of Education Quarterly, 24 (Spring 1984): 3-19; Andrea Wyman, Rural Women Teachers in the United States: A Sourcebook (Lanham, MD: Scarecrow Press, 1996). 
classical training for their sons enrolled them in local Latin grammar schools either in preparation for college or to attain the gentlemanly polish necessary to maintain or improve their social status. ${ }^{4}$ Well before the Revolution, however, it was clear that such institutions served only the privileged and the very few destined for college, and increasing numbers of communities began to support English grammar schools with the goal of offering instruction in such basic subjects as reading, writing, spelling, and arithmetic. By the close of the century, the curricula of many town and church schools expanded to include more advanced subjects such as geography. ${ }^{5}$ Kathryn Kish Sklar has documented the popular discontent with Northampton's Latin grammar school, where a town meeting in 1756 ordered the schoolmaster to "Spend no more Time with ye Latin Scholars than their Equal proportion with other Scholars." ${ }^{6}$ By mid-eighteenth century, even Boston's famous classical school faced increasing competition from local English grammar and venture schools. According to William Reese, by the mid-eighteenth century, Latin grammar schools had declined to such an extent that the colony's famous laws requiring towns to establish classical grammar schools were essentially dead letters.

In contrast to a town, church, or venture school, an academy is defined here as an institution providing a relatively advanced form of schooling that was incorporated to ensure financial support beyond that available through tuition alone. During the early nineteenth century, educators also used the term seminary to denote such an institution, although there are no clear institutional differences to help scholars distinguish the two. ${ }^{8}$ This is not to say that every nineteenth-century school calling itself an academy fit these criteria. It is likely that in some cases, administrators of venture schools simply attached the word "academy" to the name of their school in order to enhance its prestige. Nevertheless, for the purposes of this study, a school's articles of incorporation and financial resources, rather than its title, determine whether or not it falls into the category of an academy. A sample of 147 academies

${ }^{4}$ Joseph Kett, The Pursuit of Knowledge under Difficulties: From Self-Improvement to Adult Education in America, 1750-1990 (Stanford, CA: Stanford University Press, 1996); Patricia Cline Cohen, A Calculating People: The Spread of Numeracy in Early America (Chicago: University of Chicago Press, 1982); Edward W. Stevens, Jr., The Grammar of the Machine: Technical Literacy and Early Industrial Expansion in the United States (New Haven, CT: Yale University Press, 1995).

"See Kim Tolley, "Geography Opens the Door," in The Science Education of American Girls, 1784-1932, Ed.D. diss., University of California, Berkeley, 1996, 11-60.

${ }^{6}$ Kathryn Kish Sklar, "The Schooling of Girls and Changing Community Value in Massachusetts Towns, 1750-1820, History of Education Quarterly, 33 (Winter 1993): 511-539.

'For a brief discussion of the venture schools in colonial Boston, see William J. Reese, The Origins of the American High School (New Haven, CT: Yale University Press, 1995).

"Margaret A. Nash, "Academies," in Historical Dictionary of Women's Education in the United States, ed. Linda Eisenmann (Westport, CT: Greenwood Press, 1998), 3-6. 
analyzed for this study published school catalogs and in some instances placed newspaper advertisements during the period from 1794 to 1842 .

\section{Geographic Distribution}

We know enough about the distribution of academies throughout the country to make some tentative generalizations based on recent research. Some of the largest collections of academy material are found in northeastern archives. Perhaps this fact alone has led some scholars to conclude that the first academies originated in the North, but this is not the case. Religious groups founded many of the earliest academies in both northern and southern states. Various teaching orders in the Catholic Church established academies in the early seventeenth century, particularly in the Catholic colony of Maryland and in the French and Spanish territories. ${ }^{9}$ The Moravians opened a number of academies for women in the Mid-Atlantic states during the mid-eighteenth century. ${ }^{10}$ Some of the first academies endeavored to train students for the ministry. For instance, Irish Presbyterian ministers established schools in prerevolutionary America to serve the sons of Irish Presbyterians in the middle and southern colonies. According to Elizabeth Nybakken, more than forty-four such academies existed before 1775. ${ }^{11}$

Because religious denominations founded many of the colonial academies, it is important to qualify the view, often expressed in published texts, that academies arose in response to a growing mercantile economy. Seventeenth- and early eighteenth-century colonial academies provided a form of higher schooling to serve the professional needs of the ministry and the religious and educational needs of laypeople. In terms of creating a timeline, we might consider the colonial phase of the academy movement to have lasted roughly from the late seventeenth to the late eighteenth century. The institution that proliferated in response to increasing commercialism in the colonies appears to have been the venture school, and as the following discussion will show, the next phase of the academy movement saw many preexisting venture schools incorporate as academies. This period, running roughly from 1790 to the Civil War, represents the period largely addressed by Sizer in his essay; we might consider this era the heyday of the academy movement.

"Nikola Baumgarten, "Catholic Education," in Historical Dictionary of Women's Education in the United States: 68-71. See also Baumgarten's "Education and Democracy in Frontier St. Louis: The Society of the Sacred Heart," in History of Education Quarterly, 34 (Summer 1994): 171-192.

${ }^{10}$ Beverly Prior Smaby, The Transformation of Moravian Bethlebem: From Communal Mission to Family Economy (Philadelphia: University of Pennsylvania Press, 1988).

"Elizabeth Nybakken, "In the Irish Tradition: Pre-Revolutionary Academies in America," History of Education Quarterly, 37 (Summer 1997), 163-183. 
During that heyday, academies spread throughout all areas of the country. Ohio incorporated roughly 100 academies between 1803 and 1840, and Illinois chartered at least 125 between 1818 and 1848. By the 1830s, both Indiana and Iowa established "County Seminaries" built on land granted by the state. During the years from 1800 to 1840 , newspaper advertisements in such southern states as North Carolina and Virginia indicate that northern teachers emigrated to teach at new and expanding academies in the South. By the 1830s, there were as many as 24 incorporated academies in Alabama and 55 in Virginia. ${ }^{12}$ Over the next thirty years, the number of academies in Virginia increased more than sevenfold.$^{13}$ According to one source, more than 580 academies in Georgia received charters between 1783 and 1860, although some of these institutions failed or merged with others. ${ }^{14}$ Texas had 97 existing academies by $1850 .{ }^{15}$ Teachers from such well-known female seminaries as Troy and Mount Holyoke traveled from the Northeast to all regions of the country as demand for their services increased.

The distribution of academies in the nineteenth century evidenced some regional variation. States that provided some form of legislative or financial support to academies appear to have experienced a greater increase in the number of these institutions than states whose support was minimal or nonexistent. For example, New York had incorporated forty academies by 1817 , a number that rose over the subsequent two decades. One reason New York invested money in academies was to train teachers for the growing common schools. In 1827 the state designated funds for academies to train teachers in special departments, and in the mid-1830s, it mandated an academy with a pedagogical department in each senatorial district. ${ }^{16} \mathrm{In}$ contrast, territories that joined the union relatively late in the century seem to have focused their efforts primarily on the development of public secondary schools rather than academies. For instance, in California, the school that is recorded as being the first to be opened in the newly acquired territory was a small venture school established in 1846 . That school served

${ }^{12}$ See Sizer, Age of the Academies; Paul E. Belting, The Development of the Free Public High School in Illinois to 1860 (New York: Arno Press, 1969); Reese, Origins of the American High School, $29 \mathrm{ff}$.

${ }^{13}$ The 1860 census reported 398 academies in Virginia. See Dale Greenwood Robinson, The Academies of Virginia, 1776-1861 (Richmond, VA: Dietz Press, 1977), 55-56.

${ }^{14}$ Edgar W. Knight ed., A Documentary History of Education in the South before 1860 (Chapel Hill: University of North Carolina Press, 1953), vol. 4, 1.

"Henry Barnard, "Educational Statistics of the United States in 1850," American fournal of Education, I (1855), 368.

${ }^{16}$ See George Frederick Miller, The Academy System of the State of New York [1922] (New York: Arno Press, 1969); see also Nancy Beadie, "From Student Markets to Credential Markets: The Creation of the Regents Examination System in New York State, 1864-1890," History of Education Quarterly 39 (Spring 1999): 1-30; and idem., "Market-Based Policies of School Funding: Lessons from the History of the New York Academy System," Educational Policy 13 (3): 296-317. 
approximately twenty-five students and operated for a mere two months. Six years later, California had its first female academy. Managed by an allmale board of trustees, the Young Ladies Seminary opened in Benecia in 1852 "for the higher education of the daughters of the pioneer families of California without the necessity of making the long ocean voyage to New York and severing family ties." ${ }^{17}$ During the next several decades, however, Californians devoted their energies to the establishment of public high schools rather than academies..$^{18}$ Events in Utah followed a similar course. The first schools providing a form of secondary education were venture schools. The Union Academy, an institution for boys and young men, was established by Orson Pratt in 1860 with an appropriation from the Mormon Church council and the support of Brigham Young. Tuition at the academy was free, but the school closed after seven years because of lack of patronage. ${ }^{19}$ Despite such examples of regional variation, academies proliferated in many areas of the country. In 1855 Henry Barnard reported over 6,100 incorporated academies with enrollments nine times greater than in the nation's colleges. ${ }^{20}$

\section{From Venture School to Academy}

In order to understand how the academies evolved from the eighteenth to the nineteenth centuries, it is important to explore the relationship between the academies and the early venture schools. Following Sizer, scholars have viewed academies as representing a distinct break with traditional classical education. However, during the colonial period, denominational academies by and large offered the kind of classical instruction common to institutions aiming to train students for the ministry. A few early reformers argued that academies should be established to promote useful learning. Examples that are often cited in the secondary literature include Benjamin Franklin's call in $\mathbf{1 7 4 7}$ for an English (as opposed to a Latin or classical) academy that would teach both the sciences and the ornaments, ${ }^{21}$ and Benjamin Rush's short-lived chemistry course at the Young Ladies' Academy in Philadelphia in 1787..$^{22}$ Nevertheless, during the eigh-

\footnotetext{
${ }^{17}$ Charles Burgess, "Abiding by the "Rule of Birds": Teaching Teachers in Small Liberal Arts Colleges," in Places Where Teachers are Taught eds. John I. Goodlad et al. (San Francisco, CA: Jossey-Bass, 1990), 87-135.

${ }^{18}$ William Warren Ferrier, Ninety Years of Education in California, 1846-1936 (Oakland, CA: West Coast Printing, 1937).

${ }^{19}$ See Laverne Clarence Bane, The Development of Education in Utab, 1870-1895. (Ph.D. diss., Stanford University, 1940).

${ }^{20}$ See Reese, Origins of the American High School, 30-31.

${ }^{21}$ See Sizer, Age of the Academies, 70-71.

${ }^{22}$ Wyndham D. Miles and Harold J. Abrahams, "America's First Chemistry Syllabusand-Courrse for Girls," in School Science and Mathematics, 58 (1958): 111-118. For a general overview of Enlightenment reformers, see Lorraine Smith Pangle and Thomas L. Pangle,
} 
teenth century, such experimental academies were the exception rather than the rule. The eighteenth-century institution commonly providing some form of higher schooling in "useful and practical subjects" was the venture school.

Within the context of a rapidly expanding mercantile economy, eighteenth-century educational entrepreneurs established venture schools to attract students seeking more specialized study or an education more suited to business. In both rural and urban areas boys, and sometimes girls, could receive instruction from private schoolmasters or in venture schools, institutions that provided instruction in whatever subjects students paid to study. For example, Robert Leeth's school placed an advertisement in the New York Gazette-Weekly Post Boy in 1751, offering instruction to both sexes in "two handsome Rooms, with Fire-places, the one for Boys and the other for Girls." ${ }^{23}$ Newspaper advertisements of this period reveal a plethora of venture schools calling themselves "day schools," "evening schools," "select schools," "boarding schools," and so on.

After the Revolution, venture schools proliferated to meet the needs of an expanding population. Many venture schools offered instruction at a variety of times during the day or evening. Some schools opened as early as 5:00 a.m. and closed as late as 9:00 p.m. in order to accommodate the needs of working students. While rural venture schools offered such traditional instruction in elementary reading, writing, and arithmetic, venture schools located in towns and commercial areas commonly offered a larger range of subjects, including the classics and such technical courses as surveying, navigation, astronomy, geography, geometry, trigonometry, penmanship, accounting, and mapmaking. For instance, in 1824 the American Mercury in Hartford, Connecticut, carried advertisements for a number of venture schools, including one calling itself simply "A New School" which offered instruction for boys in "reading, writing, arithmetic, grammar, geography and history, mathematicks [sic], surveying, navigation, and mensuration." Students had to pay an additional charge for the last four subjects. ${ }^{24}$ The Mercury also carried advertisements for Mrs. Whale's Dancing School, offering "separate times for men and ladies, ${ }^{25}$ a Writing Academy in which students learned the "Mercantile Running Hand" in 14 lessons, ${ }^{26}$ a Music School, ${ }^{27}$ and a variety of institutions billing themselves as schools "for young

The Learning of Liberty: The Educational Ideas of the American Founders, (Lawrence: University Press of Kansas, 1993.)

${ }^{23}$ Quoted in Thomas Woody, A History of Women's Education in the United States, 1 (New York: The Science Press, 1929), 225.

24“A New School," The American Mercury (Hartford, Connecticut: June 15, 1824).

2s"A Card," in ibid., June 13, 1820.

26"Writing Academy," in ibid., May 1820.

27"Music School," in ibid., October 1824. 
ladies. ${ }^{28}$ Newspapers in both northern and southern states carried similar advertisements during the early nineteenth century.

In many cases, women opened venture schools in order to support themselves financially through teaching. Cases well known to historians include the Beecher sisters, Mary Lyon, Sarah Pierce, Zilpah Grant, Emma Willard, and others. More obscure examples are easily found in archival sources, such as the case of the Nash and Lollock Select Boarding and Day School for Young Ladies in Hillsboro, North Carolina. The school originated after the death of Judge Frederick Nash in 1858. Judge Nash left an estate too small to adequately support his wife and two daughters. As a result, the Judge's daughters decided to open a school in their home. ${ }^{29} \mathrm{Mar}-$ ried women also sometimes opened venture schools. For example, Susan Nye Hutchison, formerly a teacher at Raleigh Female Academy in North Carolina, returned to teaching during a period when her family faced financial ruin. After her husband lost the good part of his fortune speculating on the cotton market in 1827, she wrote in her diary that "My husband spoke with great feeling of his continued losses and expressed his wish that I should return to town to open a school." ${ }^{30}$

There currently exists a great deal of confusion in secondary sources concerning the distinction between venture schools and academies. For example, historians frequently claim that Sarah Pierce founded Litchfield Academy in $1792^{31}$ and that Catharine and Mary Beecher opened an academy in Hartfield, Connecticut, in $1823 .{ }^{32}$ Both of these statements are inaccurate. In 1792, Sarah Pierce opened a school for girls in the dining room of her home in Litchfield, Connecticut. During the next several years, that school placed newspaper advertisements to attract students, first as "Miss Pierce's School for Girls" and later as "The Litchfield School for Young Ladies." While scholars often refer to this little venture school as the Litchfield Female Academy, the school was not incorporated as an academy until 1827 when it took that name. Similarly, Catharine and Mary Beecher opened a school in 1823, placing newspaper advertisements to attract students. Those advertisements show that the Beechers called this institution "Catharine and Mary Beecher's School for Girls." ${ }^{33}$ This small school, located over a harness shop on Main Street in Hartford, was clearly an entrepreneurial effort, deriving its support from tuition without an established board of trustees.

${ }^{28}$ For example, "Mrs. Grovesnor and Mrs. Sheldon's School for Young Ladies," in ibid., March, 1820, and "Miss Spellman's School for Young Ladies," in ibid., April 1820.

${ }^{29}$ News \& Observer clipping, September 27, 1831, in M.C.S. Noble Papers, fol. 37, Southern Historical Collection, Chapel Hill, NC.

${ }^{30}$ Susan Nye Hutchison Diary, Aug. 1, 1827, in Southern Historical Collection.

${ }^{31}$ See Historical Dictionary of Women's Education in the United States, ed. Linda Eisenmann, 5 .

${ }^{32}$ See ibid., p. 38.

${ }^{33}$ "C \& M Beecher's School for Girls," in The American Mercury (Hartford, Connecticut: April 20, 1824). 
In The Age of the Academies, Sizer depicted the academies as part of a new educational reform effort that ultimately replaced the Latin grammar schools during the nineteenth century. Other authors have depicted the academies as representing a distinct break with the earlier venture schools. However, in many cases, academies established in the nineteenth century arose from preexisting venture schools during the postcolonial period. Venture schools could become academies through acts of state legislation or through incorporation by the local town government, private supporters, or church groups.

\section{The Founding of Academies}

A school bearing the name "academy" or "seminary" differed from a venture school in having some form of financial support other than tuition, articles of incorporation, and the oversight of a board of trustees. Incorporating a venture school as an academy provided benefits both to the academy's founders and to the community. For the founders, a source of revenue in addition to tuition allowed for the purchase of additional educational resources and the possible construction of new and larger buildings. For the community, the incorporation of an academy guaranteed a greater continuity of educational services. In contrast to the venture schools, which appeared and disappeared depending on the number of available students or the whim of the instructors, the financial stability of the incorporated academy provided a greater likelihood of survival and growth. Additionally, the creation of a Board of Trustees ensured a larger degree of accountability to the community because that board not only provided input in the selection of the school's curriculum, but also often assisted in overseeing public examinations of the students at regular intervals during the school year.

Some early academies were established through state legislation. In North Carolina, the term "academy" in reference to an educational institution first appeared in a letter written July 20, 1766, by Reverend James Reed about a venture school at New Bern. In 1764, Thomas Tomlinson had opened a private school there. Through the advocacy of the Reverend Reed and others, on November 10, 1766, a Mr. Cogdell introduced a bill in the Colonial Assembly to incorporate the school. The bill passed and became the first charter issued to a private school in the colony of North Carolina. In 1784, the school changed its name from New Bern School to New Bern Academy. By the end of the century, the legislature had granted charters to thirty-four academies, two of which, Martin Academy and Davidson Academy, were located in Tennessee. ${ }^{34}$

\footnotetext{
${ }^{34}$ News clipping: "The Academy: the Forerunner..." in M.C.S. Noble Papers, fol. 37, Southern Historical Collection, Chapel Hill. For a discussion of academies in New York, see Nancy Beadie, "Defining the Public: Congregation, Commerce and Social Economy in the Formation of the Educational System, 1790-1840," (Ph.D. diss., Syracuse University, 1989.)
} 
In other cases, private supporters provided the financial backing necessary to incorporate a venture school as an academy. For example, Warrenton Female Academy in North Carolina originated as a venture school started by a Mrs. Turner. According to a former teacher at the academy, Mrs. Turner's husband "was not of the accumulative kind, and she had resorted to this method of obtaining a living." The school served both day students from the town and boarders, primarily planters' daughters from the surrounding country. "[Mrs. Turner] ran the school quite successfully for a few years, and at her death, some of the planters around Warrenton purchased and continued the school." ${ }^{35}$

\section{Curriculum}

In contrast to the narrow classical focus of the Latin grammar schools, nineteenth-century academies offered a much broader range of subjects. Newspaper advertisements placed by academies often listed the traditional subjects of English, Latin, Greek, declamation, writing, arithmetic, and some portion of the newer subjects of French, geography, logic, geometry, and natural philosophy or astronomy. ${ }^{36}$ This contrast formed the basis for Sizer's argument that the academies represented a curricular revolution in American education. However, when compared with preceding institutions, it can be argued that the curricula of the academies also evidenced a great deal of continuity.

Many of the larger nineteenth-century academies continued the tradition of the earlier Latin grammar schools by maintaining a separate department in which students could pursue the classical course of study. For instance, in 1836 Hemdon Academy in North Carolina offered both a "Classical Department" and an "English Department," with different rates of tuition for each, payable in advance. Tuition for "common English scholars" was $\$ 7.50$ per session, whereas tuition for "Latin or Greek Scholars" was $\$ 12.50 .{ }^{37}$ Although there is insufficient research on Latin grammar schools to be able to draw any general conclusions, some academies originated as Latin grammar schools. For instance, such New York academies

\footnotetext{
${ }^{35}$ Maria Florilla Flint Hamblen Reminiscences, September 1860-June 1861," in Flint Papers, fol. 1, Southern Historical Collection, Chapel Hill.

${ }^{36}$ North Carolina Schools and Academies 1790-1840: A Documentary History ed. Charles L. Coon (Raleigh: Edwards \& Broughton, 1915). See the newspaper advertisements for the following male academies: Pittsborough Academy (1800), 35; Hillsborough Academy (1801), 280; Caswell Academy (1802), 18; Franklin Academy (1804), 84; Edenton Academy (1805), 326; Hyco Academy (1805), 22-3; Salisbury Academy (1807), 346-7; Kilpatrick's School (1809), 382. Several North Carolina female academies or seminaries also offered geography during the first decade of the nineteenth century: Fayetteville Academy, Female Department (1801), 60-1; Raleigh Academy, Female Department (1806), 396; Mordecai's Female Seminary (1808), 595; Mrs. Milligan's School (1807), 229; Mrs. Gregory's Boarding School (1808), 295.

"37"Herndon Academy," in Raleigb Register, December 13, 1836.
} 
as Schenectady Academy (1771), Washington Seminary (1776), and Farmer's Hall (1784), developed as classical schools first and later broadened their curricula to attract a larger student population. ${ }^{38}$ Although many scholars have portrayed academies as institutions that emphasized practical, useful subjects as opposed to the classics, Latin remained one of the three most studied subjects in academies throughout most of the nineteenth century. ${ }^{39}$

The academies also drew from the tradition of the venture schools which offered a range of subjects for students to select. To some extent, although the early academies developed established courses of study, their students also had a great deal of flexibility beyond the basic subjects of reading, writing, and arithmetic. The published tuition rates at both northern and southern academies indicate that students almost always had to pay extra for instruction in languages and the classics or for such ornamental subjects as painting or fancy needlework. For example, at Union Academy in Bennington, Vermont, the 1834 school catalog listed the following rates:

"For common English studies...\$3.00

For geometry, algebra, natural and intellectual philosophy...\$3.50

For French, Latin and Greek Languages, and Chemistry...\$4.00"40

In 1840, Utica Female Academy charged $\$ 3.00$ each for instruction in chemistry, botany, conchology, Latin, and French but charged $\$ 7.00$ for drawing, flower painting, and so on. ${ }^{41}$ Academies serving male students often charged extra for instruction in such subjects as navigation and surveying.

Sizer argued that the academies represented a distinctly new turn in the history of education because in contrast to the earlier Latin grammar schools, they offered a wider range of curricular choice and served a broader clientele. As an intellectual historian, he also argued that the impetus for this curricular shift was the new Enlightenment philosophy of education espoused by such leaders as Benjamin Franklin, Thomas Jefferson, and Benjamin Rush. The documentary evidence examined in this study suggests another interpretation. The major competitor to the Latin grammar school was the eighteenth-century venture school, not the nineteenth-century academy. Additionally, venture schools offered a broad, nonclassical curriculum well before the period when Franklin, Jefferson, or Rush wrote about the need to introduce such subjects into publicly supported schools.

\footnotetext{
${ }^{38}$ George Frederick Miller, The Academy System of the State of New York (Albany, NY: J. Lyon Col, 1922).

${ }^{39}$ This point was noted by Sizer in Age of the Academies, 36.

${ }^{40}$ Union Academy, Catalogue for the year, ending September 4, 1834 (Bennington, VT: J.C. Haswell, 1834), 13.

${ }^{41}$ Catalogue of the Officers and Members of the Utica Female Academy, During the Year Ending August 6th, 1840 (Utica, NY: Bennet, Backus \& Hawley, Frankline Square, 1840), 21.
} 
The venture schools arose in response to a public demand for practical training within the context of an expanding population and a growing mercantile economy. Seeking the financial backing necessary to the establishment of an academy, the founders of such institutions often invoked the Enlightenment ideas expressed by such well-known and respected leaders as Jefferson. In such cases, the theories being invoked often served as useful rhetoric to justify support for a preexisting curriculum. In 1799, when Benedict Arnold wrote to Bartholomew Booth concerning the subjects his two sons might study at Booth's school, he asked that his children receive a practical education, not because of the inherent value of an Enlightenment curriculum over the classics, but because of the political and financial uncertainty of the new country: "I want their education to be useful rather than learned. Life is too short and Uncertain to throw away in Speculation on Subjects that perhaps only one Man in Ten thousand has a Genius to make a figure in. You will pardon my dictation to you, Sir, but as the fortunes of every man in this country are uncertain, I wish my Sons to be educated in such a manner that with prudence and Industry they may acquire a Fortune, in case they are deprived of their patrimony, as well as to become Useful Members of Society." ${ }^{2}$

Although the academies generally can be distinguished from other institutions by the greater breadth of their curricula, it is important to acknowledge their continuity with both the venture schools and the Latin grammar schools. To a great extent, the academies synthesized some of the curricula and pedagogy of both institutions.

\section{The Significance of the Academies in Higher Schooling}

How did the academies change the character of higher schooling in the United States? The establishment of academies in the nineteenth century formalized the freewheeling entrepreneurial schooling offered by the early venture schools. Venture schools embraced change as quickly as the market demanded it, offering every useful subject prospective students might wish to study. To be competitive, the early academies followed suit, and thus the entrepreneurialism of the venture schools facilitated a widespread curricular reform in higher schooling. Even the sectarian Protestant and Catholic academies included the newer curricular offerings in their courses of study. The distinction between the academies and venture schools lies not in the curriculum they offered so much as in the degree of stability and accountability the academies represented. The rise of the academies

${ }^{42}$ Quoted in Maurice Whitehead, The Academies of the Reverend Bartbolomew Booth in Georgian England and Revolutionary America; Enligbtening the Curriculum (Lewiston, ME: Edwin Mellen Press, 1996), 102. 
resulted from the desire on the part of many local communities and some states to institutionalize a level of study that was both broader and more advanced than that attainable in common schools or in the early Latin grammar schools. With the creation of boards of trustees to oversee the development of curriculum and assessment, academies also became more accountable to the community for the quality of their students' learning.

In contrast to many eighteenth-century academies, many newly founded nineteenth-century academies were broadly Protestant but nondenominational. For example, the 1835 prospectus of Mount Holyoke Seminary stated that the school would "raise among the female part of the community a higher standard of science and literature, of economy and of refinement, of benevolence and religion." ${ }^{43}$ Such claims could potentially attract students from a variety of religious backgrounds and still assuage the concerns of parents who desired some blandly Protestant form of moral and religious education for their children. The number of Catholic academies increased also from the 1830 s, numbering over 660 by the century's end. According to Nikola Baumgarten, they enjoyed a significant Protestant clientele. ${ }^{44}$ Newspaper advertisements placed by Catholic academies show a great deal of similarity to the advertisements of non-Catholic academies and venture schools. For example, in 1842 the Carmelite Sisters' Academy in Baltimore, Maryland, advertised instruction in such Enlightenmentsubjects as bookkeeping, botany, natural philosophy, astronomy, natural history, and Italian. Sacred History is the only subject appearing in that academy's advertisement indicating the presence of religion in the curriculum. ${ }^{45}$

The religious affiliation of some academies was undoubtedly among the several factors contributing to the decline of the academy as the dominant form of higher schooling. As noted earlier, a few state legislatures provided various forms of financial support to the early academies, a model that did not continue into the twentieth century. The First Amendment to the Constitution, ratified in 1791, stated, "Congress shall make no law respecting an establishment of religion...." In 1811, James Madison strengthened the boundary between church and state by writing that "The appropriation of funds of the United States for the use and support of religious societies, [is] contrary to the article of the Constitution which declares that 'Congress shall make no law respecting a religious establishment.' "46 As noted by Bruce Leslie, distinctions between public/private and religious/

${ }^{43}$ Carole B. Shmurak, s.v. "Mary Lyon," Historical Dictionary of Women's Education in the United States, ed. Linda Eisenmann (1998): 253-255.

${ }^{4}$ Nikola Baumgarten, s.v. "Catholic Education," ibid., 68-71.

45"Carmelite Sisters' Academy," Baltimore Sun (Maryland): August 12, 1842.

${ }^{46} \mathrm{James}$ Madison, The Writings of James Madison Comprising his Public Papers and his Private Correspondence, Including Numerous Letters and Documents Now for the First Time Printed, Ed. Gailla Hunt (New York: G.P. Putnam's Sons, 1900-10), 8: 133. 
secular solidified after the Civil War, while the increasing number of Catholic academies may have fueled the issue emotionally and politically. ${ }^{47}$ The historical roots of the academy in the United States had always had some association with religion. In contrast, the public high school, as a new and distinct institution, presumably stood on nonsectarian and less controversial ground.

Although differing from the entrepreneurial venture schools in the greater stability and accountability they provided, the academies also evidenced some continuity with these earlier institutions. Like venture schools, the academies maintained a degree of choice and flexibility in curricular offerings that was distinct from both the earlier Latin grammar schools and the later public high schools. The issue of choice, coupled with concerns for educational equity, continues to hold a place in the educational debates of today. In the twentieth century, the desire for greater choice expresses itself in the charter school movement and in experiments with vouchers and schools run according to an entrepreneurial business model. Although some educators and policy makers express the view that such experiments are only very recent, the desire for choice, to study on a "need-to-know" basis, has roots in the early academy movement during a time when the community's desire for stability, formality, and accountability led to a greater degree of institutional structure.

For the historian, this period of transition from the venture schools to the academies provides a fascinating area of research into a number of yet unanswered questions. First, while some scholars have claimed that by charging tuition the early venture schools and academies served elites, it is unclear whether this is the case. By offering classes at night, such schools may have provided instruction on a need-to-know basis to students who worked. Second, we need more information about the kinds of students who studied in these institutions. More research is needed to understand the extent to which venture schools, and the later academies, may have served the needs of free African-American students. Although there are many case studies of the experiences of Native-American students in religious and secular academies, and some research on the experiences of Hispanic students, there is little information about venture schools that may have served students from these and other ethnic groups. Third, research is needed before we can conclude that the venture schools declined as the numbers of academies increased. As noted by contemporaries, the drawbacks of the venture schools included their relative lack of standards and accountability and the transience of their founders and instructors. On the other hand, such institutions undoubtedly continued to fill a useful niche for students needing to gain skills in a limited number of subjects or for

${ }^{47}$ See Bruce Leslie, "Where Have all the Academies Gone?" in this issue. 
those wanting to study during more flexible hours. A perusal of the yellow pages in most cities today indicates that venture schools providing some form of higher schooling below the college level continue to exist, even if they rarely invite the attention of educational researchers. Fourth, our knowledge of the geographic distribution of academies throughout the country remains sketchy, particularly in regions like the West and Southwest. Did the academy movement appear later in the West, or did western and southwestern states largely skip the academy phase and focus on the construction of public schools? Finally, although scholars have begun to examine the role of women in the early academies, the experiences of females in the earlier venture schools is yet unknown. Documentary evidence suggests that some girls may have studied relatively advanced subjects in venture schools earlier than has been suggested by historians.

\title{
"Cultivating the Powers of Human Beings": Gendered Perspectives on Curricula and Pedagogy in Academies of the New Republic
}

\author{
Margaret $A$. Nash
}

Elizabeth Hamilton, author of the popular Letters on Education (1801), was a strong advocate of advanced education for females. When someone suggested to her that a "triumph of reason over the passions" might be unattractive in a woman, she retorted, "I beg your pardon; I thought we were speaking of the best method of cultivating the powers of buman beings. . . . In this I can make no distinction of sex" [italics in original]. ${ }^{\prime}$ Most writers on edu-

Margaret A. Nash is an assistant professor at the University of Toledo. She earned her Ph.D. from the University of Wisconsin-Madison, where she wrote a dissertation on higher education for women in the United States, 1780-1840. Her work appears in the Fournal of the Early Republic and the History of Higher Education Annual. She would like to thank Michael Fultz, Jeanne Boydston, Bill Reese, Kim Tolley, Nancy Beadie, Bruce Leslie, and the HEQ reviewers.

'Elizabeth Hamilton, Letters on Education (Dublin: H. Colbert, 1801), 15, 28-29. 